\title{
The Torbrook Formation
}

Lyndon R. Jensen

Department of Geology, Dalhousie University, Halifax, Nova Scotia

\section{Introduction}

The Lower Devonian Trobrook Formation crops out in two areas within the core of a tightly folded syncline (see Fig. 1 of Lane, Stratigraphy of the White Rock Formation, this volume). One area is represented by a single significant exposure at Bear River. The other occurs in the central Annapolis valley, where the formation is exposed along Spinney and Messenger Brooks (for locations, see Lane's Fig. 2). The total thickness, as measured at Spinney Brook, is $1434 \mathrm{~m}$.

This report is based primarily on a dissertation study (currently in progress) of the lithology, sedimentary structures, fossils and trace fossils of the strata exposed along Spinney Brook. A generalized stratigraphic column of the Spinney Brook section (Fig. 1) shows the vertical succession of sedimentary structures and textures. The upper part $(434 \mathrm{~m})$ of the section is not exposed at Spinney Brook and, therefore, is not included in Figure 1. A sketch-map showing the precise location of the outcrops appears as Figure 2 .

A rich shelly fauna ranging in age from Early Gedinnian to Sigennian, and possibly Emsian, is represented. The shelly beds of the Torbrook Formation are the only highly fossiliferous strata known within the Meguma Belt. Boucot (1960) pointed out that the brachiopod fauna have Rhenish rather than Appalachian affinities. Further evidence of a European faunal association is the presence of several species of the trilobite Acastella, not previously reported in North America (A. Ormiston, personal communication).

\section{The Spinney Brook Section}

At Spinney Brook, the Torbrook Formation is underlain conformably by black graptolitic shale and dark grey silty shale of the Upper Silurian Kentville Formation. The contact between the two formations is defined as the first appearance of sandstone. The Torbrook Formation consists primarily of interbedded silt-rich to clay-rich mudstone, coarse siltstone and very fine-grained sandstone with subsidiary arenaceous coquinite. An $84-m$ interval of intercalated limestone and calcareous arenite occurs in the middle of the section. The succession along Spinney Brook is depicted in Figure 1. Examples of the sedimentary structures that characterize these strata are shown in Figs. 3 to 25.

In the basal $30 \mathrm{~m}$ of the formation, silty mudstones coarsen upward to muddy sandstones (Fig. 1). These beds are characterized by parallel-lamination and some ripple-lamination (Figs. 3 and 4). A heavily iron-stained fossil horizon with a varied marine fauna capped by a thin, flat stromatoporoid layer occurs near the top of this relatively unfossiliferous interval. This coarsening-upward zone is tentatively interpreted to represent a period of regression (shallowing water-depths). The depositional environment is difficult to interpret more precisely than this, partly because the depositional characteristics of the conformably underlying Kentville Formation are not fully understood. A massive sandstone at $57 \mathrm{~m}$ records an increase in the supply of coarse sediment. An unfossiliferous dark shale sharply overlies this sandstone and possibly represents a rapid return to relatively deeper-water conditions of deposition.

From $69 \mathrm{~m}$ to $175 \mathrm{~m}$ (Fig. 1), the succession coarsens upward and contains highly fossiliferous sandstone beds. The allochthanous faunal assemblages (coquinas) and parallel-laminated sandstones found here suggest that the depositional environment was a storm-dominated lower shoreface or inner shelf. This interval is discussed in detail in the next section.

Above the 175-m horizon, the strata consist of highly bioturbated sandy mudstone and lenticular silty mudstone, and generally thin interbeds of sandstone. The sandstones increase upward in number and thickness. At $230 \mathrm{~m}$, the mudstones become relatively fine-grained (clay-rich), contain numerous thin silt "whisps" (Figs. 15 and 16), and possess a bivalve faunal assemblage. Several sandstone beds, each a few metres thick, occur at the top of this interval (to $254 \mathrm{~m}$ ). The upward increase in the proportion of coarse-grained sediments in this part of the succession is very gradual. This and other factors, such as the presence of plant fragments and an ostracod fauna, suggest marine deltaic deposition.

The overlying sediments have characteristics that suggest low rates of deposition and restricted circulation. These include thin sandstone beds with phosphatic pebbles, intercalated with silty mudstones (Fig. 17), thin oolitic iron beds (Fig. 18), dark pyritic mudstones and limey sandstones. The presence of oolitic iron, corals, and the localized development of abundant pyrite and minor hydrocarbons suggest shallow-water deposition in a relatively restricted environment (probably an estuary or shallow bay). Overlying tuffs and mudstones (to approximately $700 \mathrm{~m}$ ) also were deposited in shallow water, as verified by the presence of a sparse lingula-rich fauna.

The remainder of the section consists of thickbedded sandstones with composite cross-lamination, interlayered with lenticular, occasionally highly bioturbated silty to sandy mudstones and muddy sandstones. The proximity of these sediments to an ancient shoreline is suggested by the presence of abundant plant remains, and by the red coloration which may be the result of primary oxidation. Also, some of the sedimentary structures indicate intermittent subaerial emergence within an intertidal regime (tidal-flat and-channel deposits). 


\section{Sedimentary structures:}

TEXTURE:
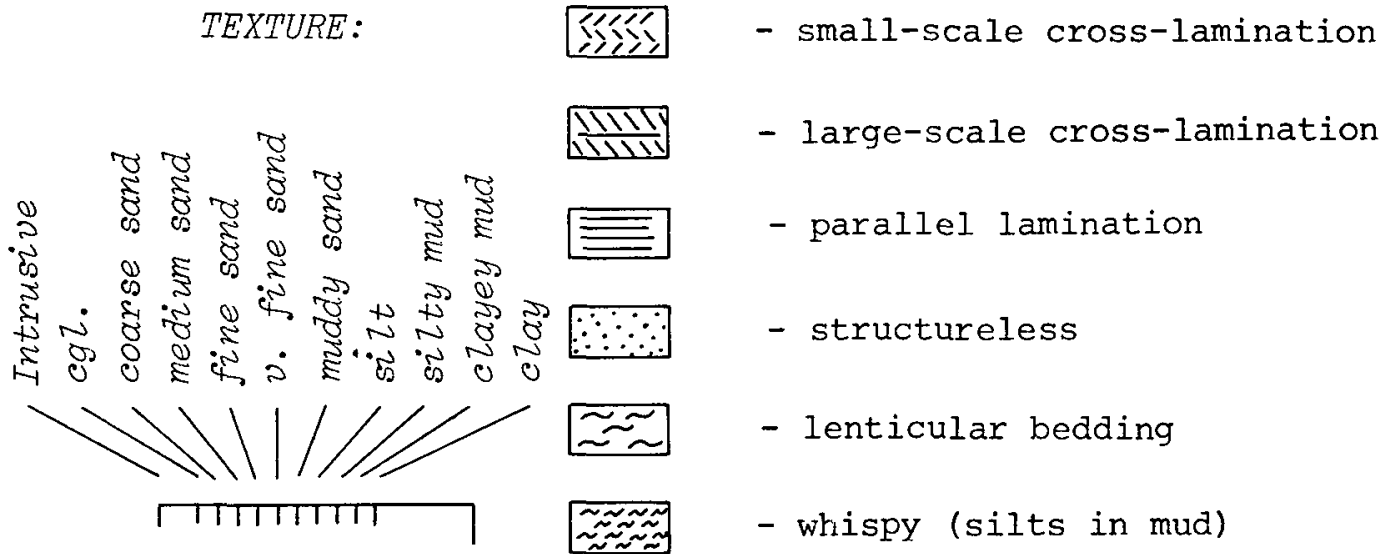

IIIII - large-scale cross-lamination

$\equiv$ - parallel lamination

$\because \because \because \quad$ - structureless

$\widetilde{\sim} \sim$ - Ienticular bedaing

- whispy (silts in mud)

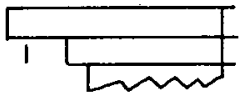

- alternating beds

- fine grained sediment

$+t_{++}^{+} \quad-$ intrusive

严济 - intercalated structures

NE. = not exposed

Bioturbation:

$$
\begin{aligned}
& Q \text { - very highly bioturbated } \\
& \theta \text { - vertical burrows } \\
& \theta \text { - inclined burrows } \\
& y \text { - rhizocorallid burrows } \\
& f \text { - condrites } \\
& \not 2 \text { - zoophycus }
\end{aligned}
$$

$$
\begin{aligned}
& \Psi \text { - sour depression } \\
& 3 \text { - interferance ripples } \\
& 8 \text { - bivalves } \\
& \uparrow \text { - plant remains } \\
& m \text { - concretionary layer } \\
& \square \text { - tentaculinids }
\end{aligned}
$$

Fig. I Stratigraphic section of the Torbrook Formation, Spinney Brook. 


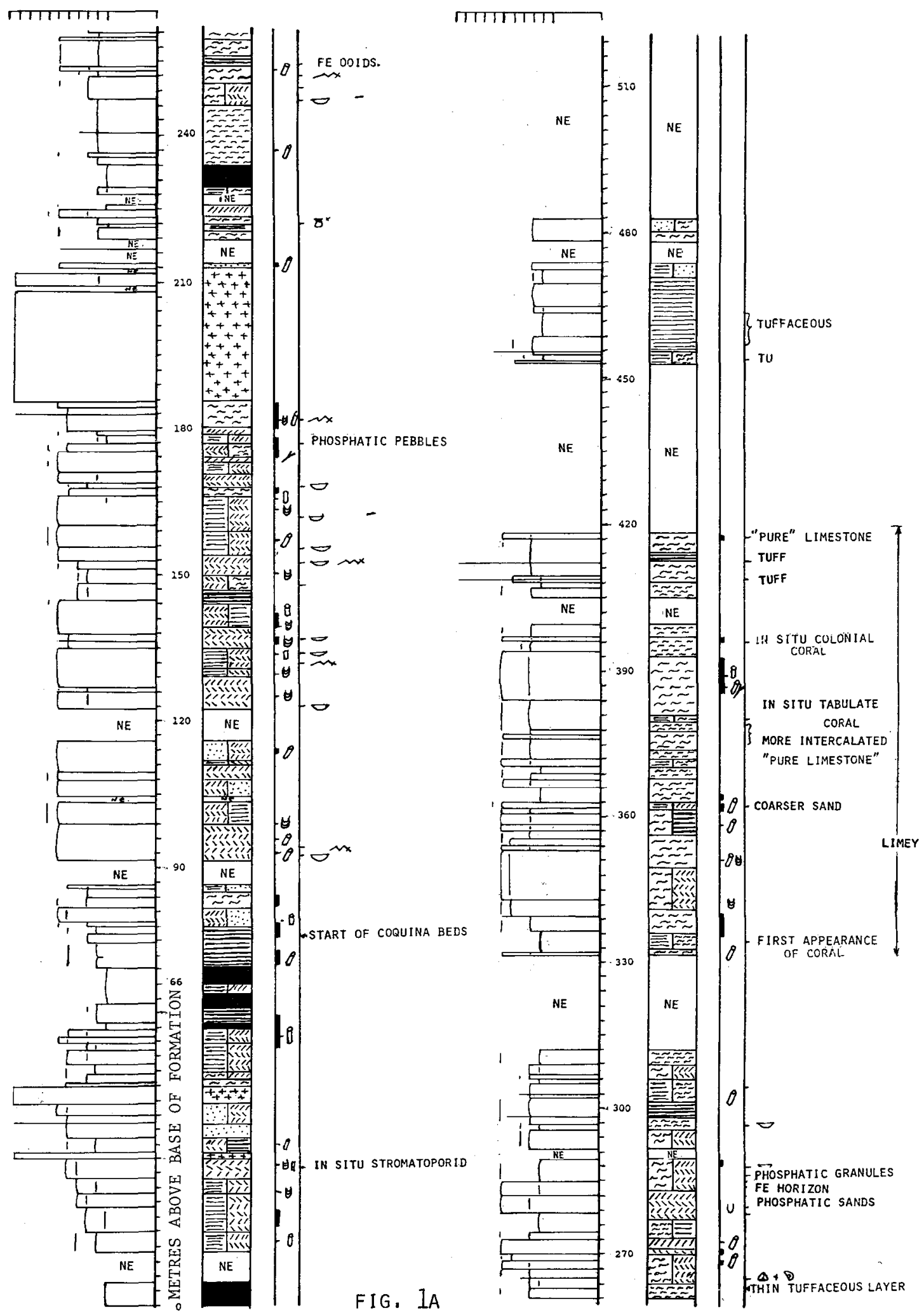




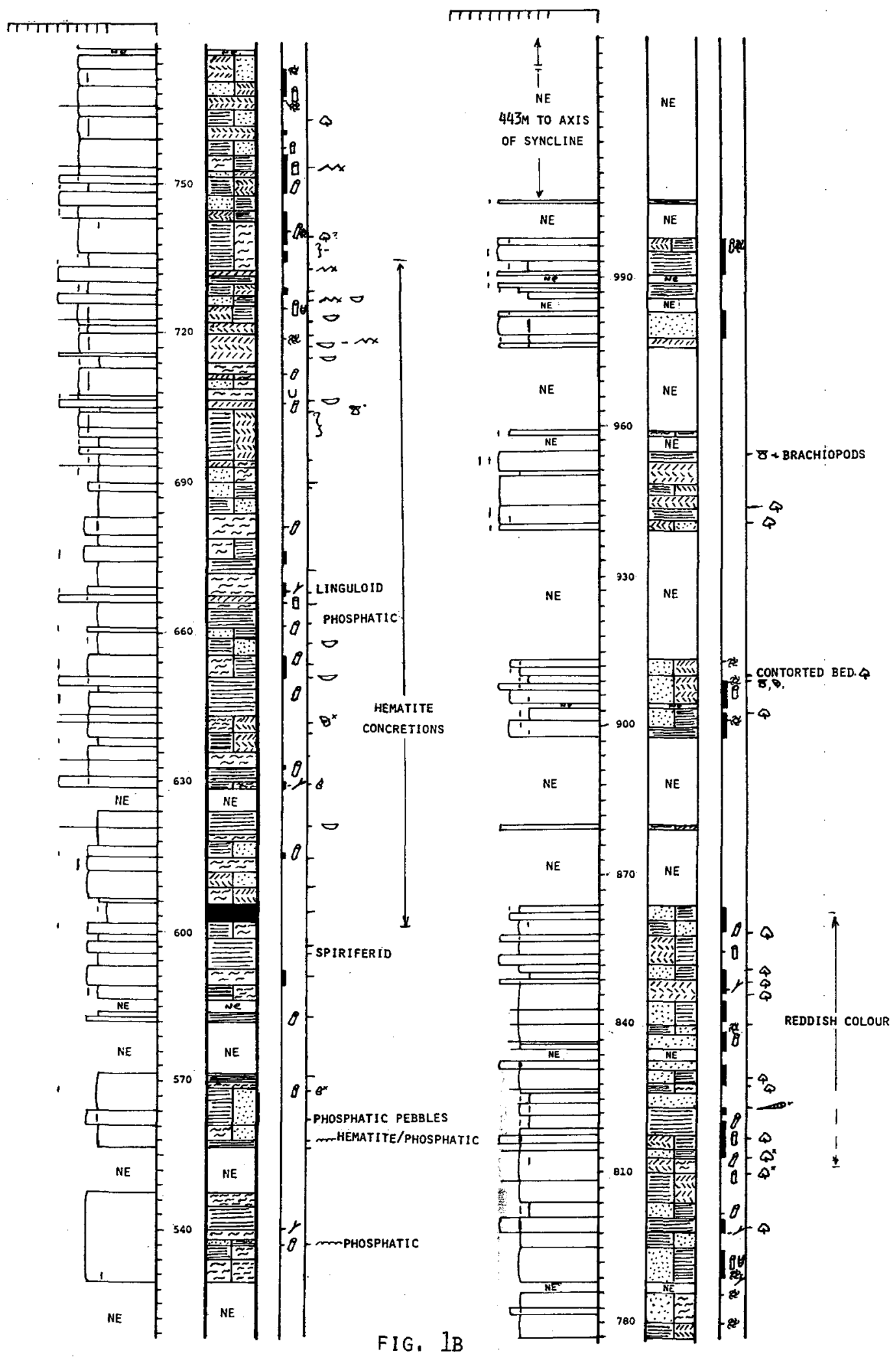




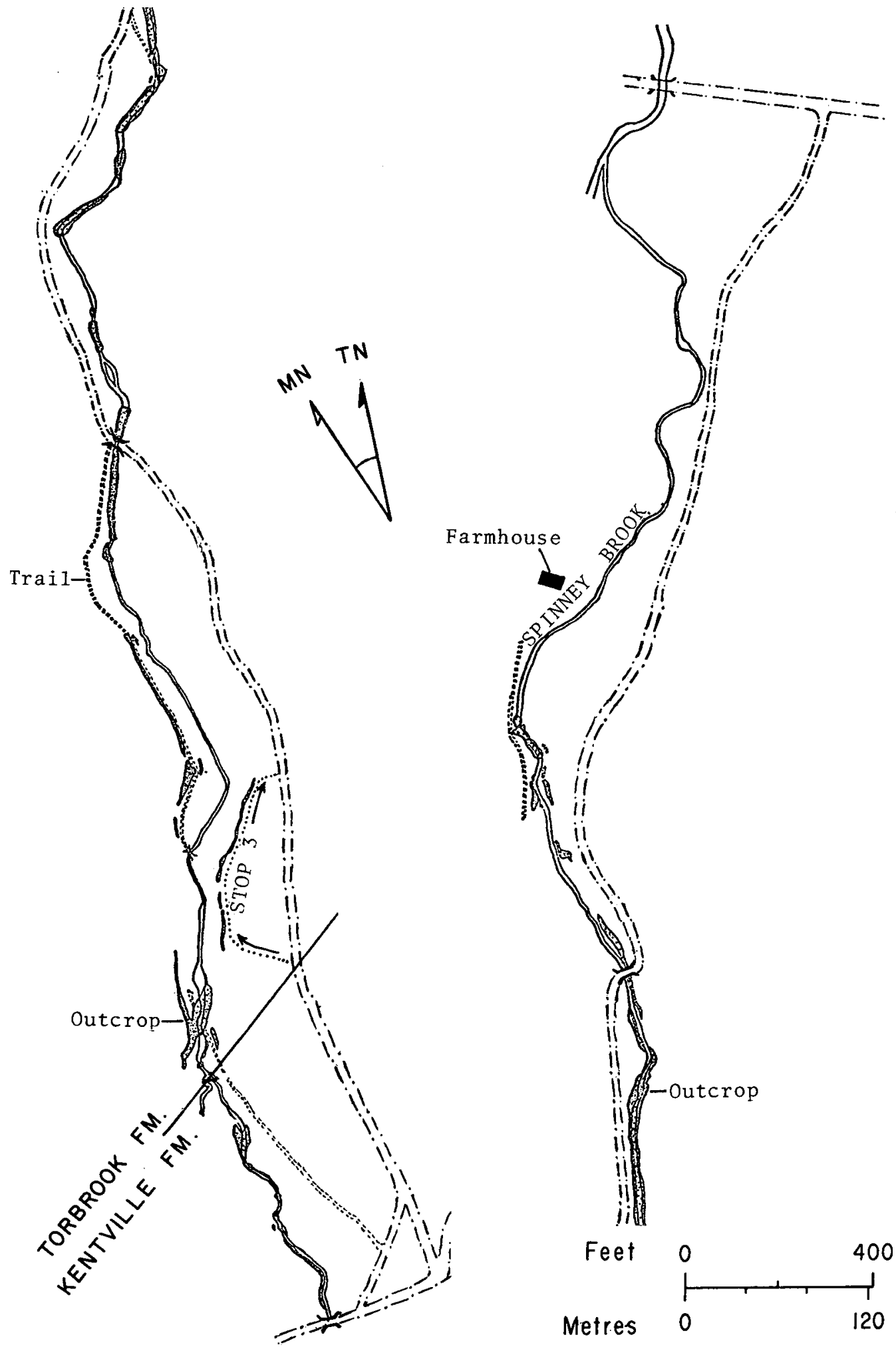

Fig. 2 Location of outcrops along Spinney Brook. (Upper left part of diagram adjoins lower right). 


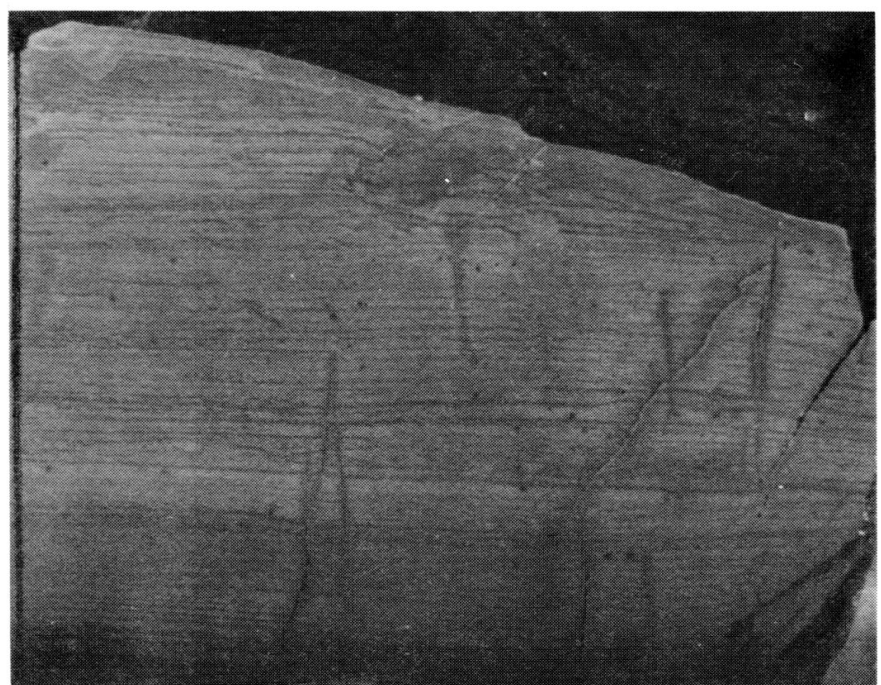

Fig. 3 Parallelolamination and minor crossolamination in siltstone near the base of the Torbrook Formation. Bar represents $9.5 \mathrm{~cm}$.

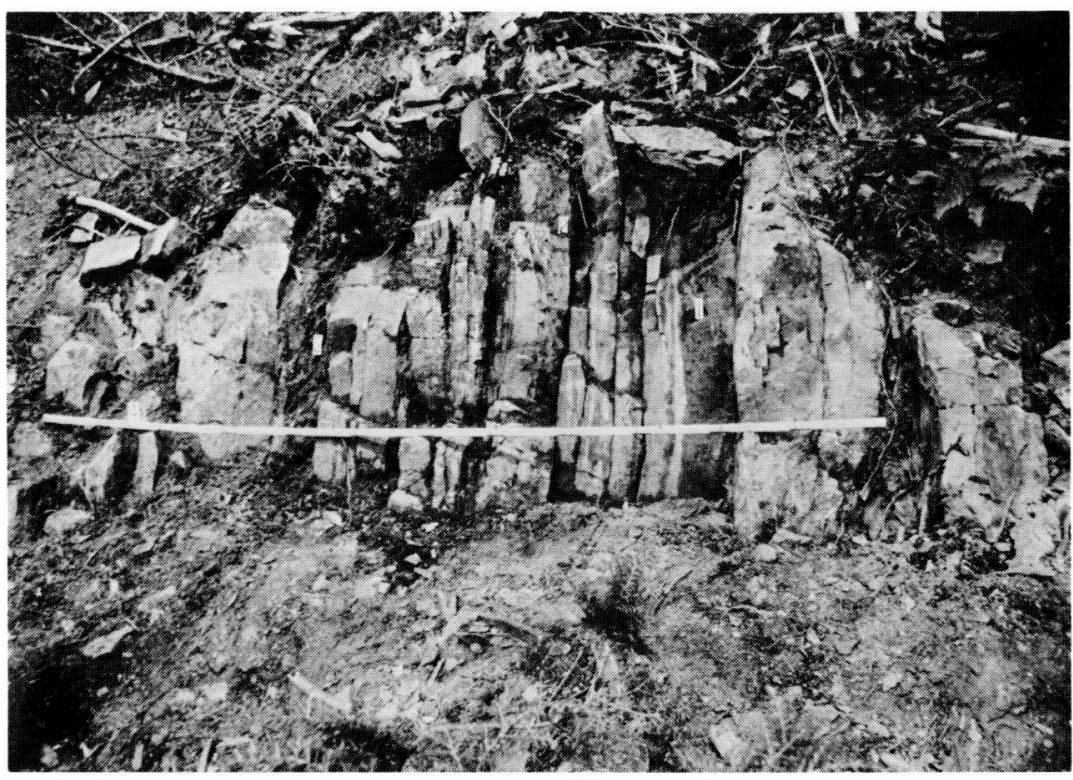

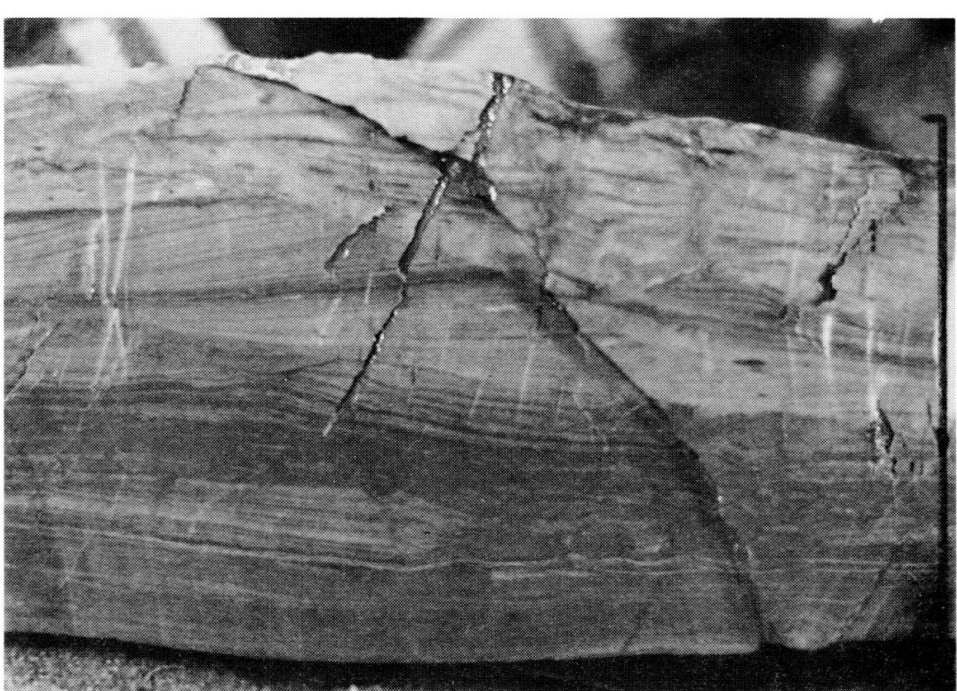

Fig. 4 Finely interlayered mudstone and siltstone in lower half of sample, and siltstone with scouroandofill crossolamination in upper half (basal Torbrook Formation). In lower half, note Parallel. and smallescale ripple. lamination, and disruption of laminae by bioo turbation. Bar represents $7.5 \mathrm{~cm}$.
Fig. 5 Laminated to structureless sandstone, with interlayered coquinite and mudstone. Length of measuring stick is 6 feet $(1.83 \mathrm{~m})$.

Fig. 6 Crossolamination in sandstone associated with truncated oscillation ripples and clay drapes. Closerup of part of the outcrop shown in Fig. 5. Length of scale is $15 \mathrm{~cm}$.

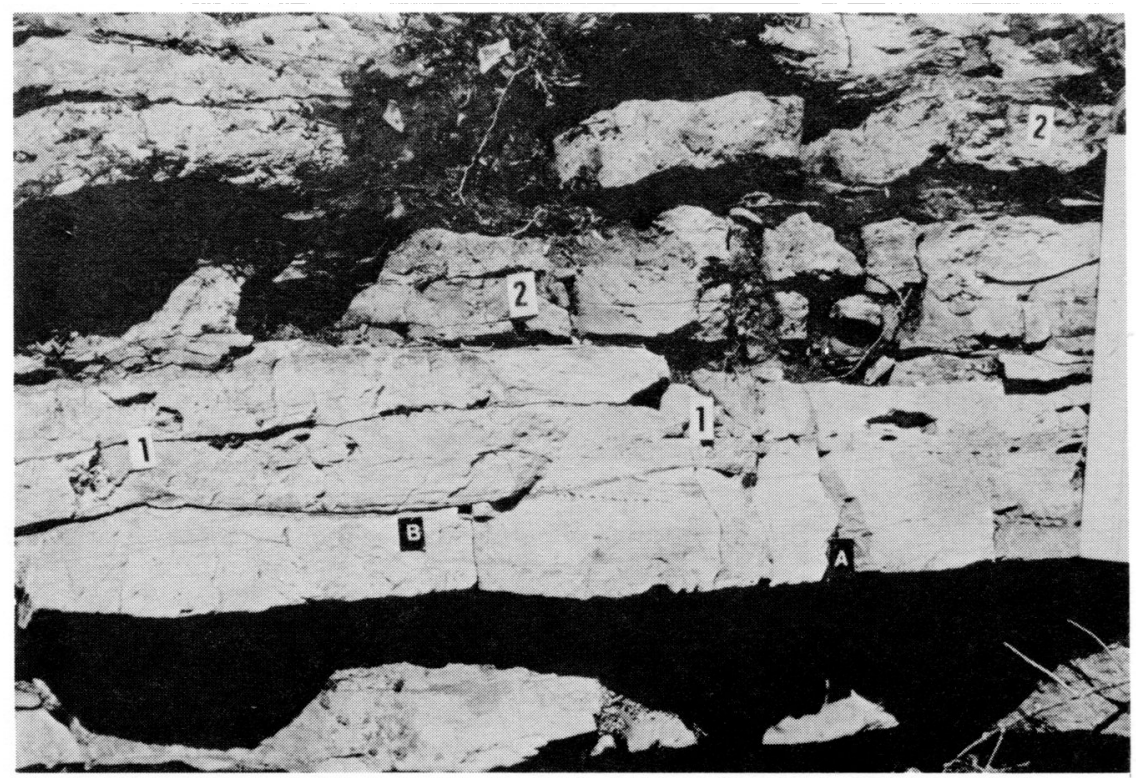




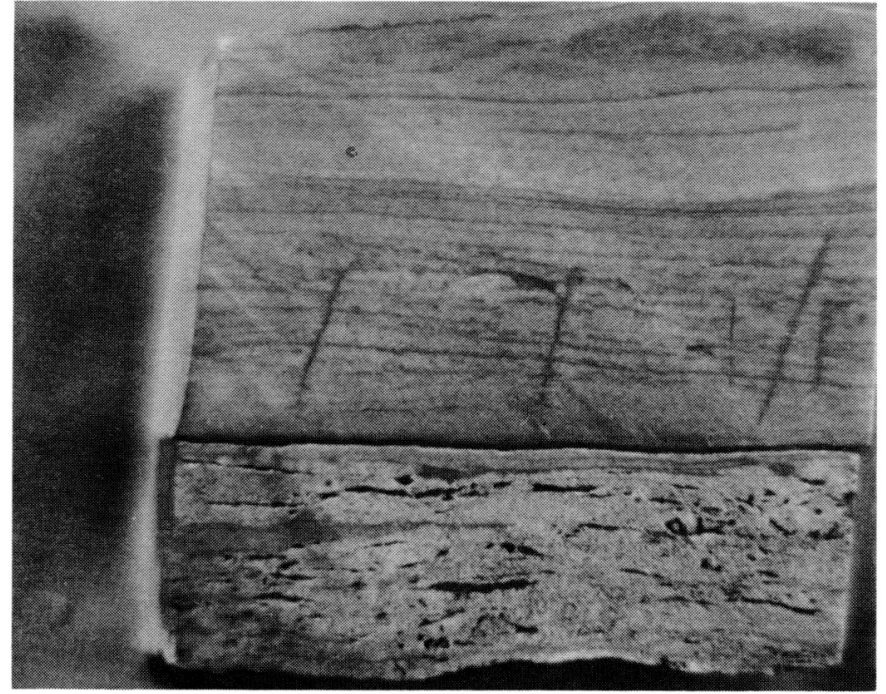

Fig. 7 Coquina layer overlain by sandstone with lowo angle crossolamination and wavy parallelo lamination. Bar represents $5.5 \mathrm{~cm}$.

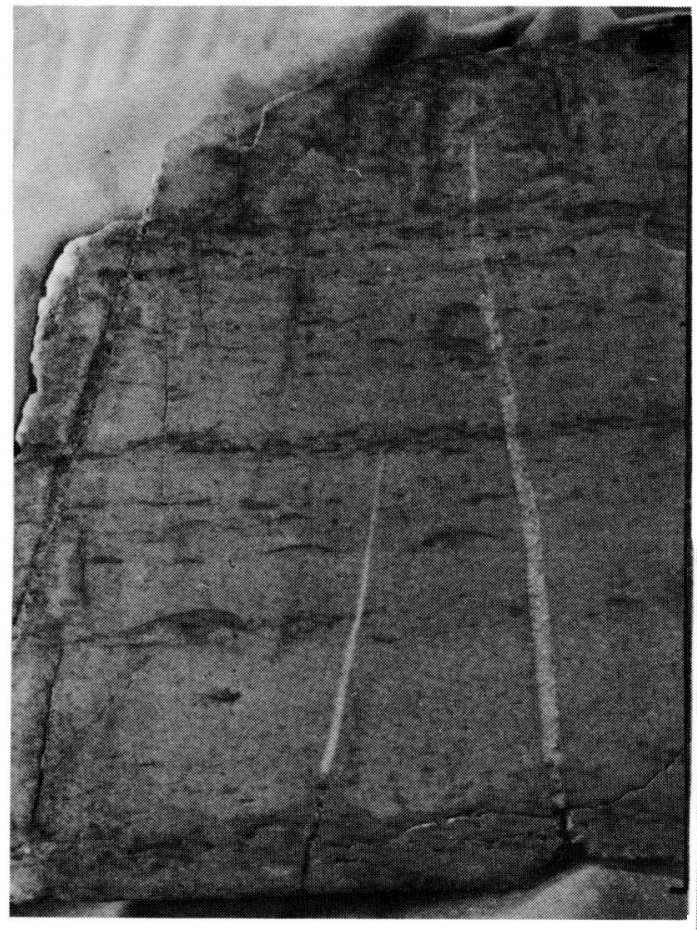

Fig. 10 Beds and lenses of sandstone with irregular sharp bases, intero calated with silty mudstone. Both the sandstone and mud. stone are extensively bioturo bated. Bar represents $7.3 \mathrm{~cm}$.

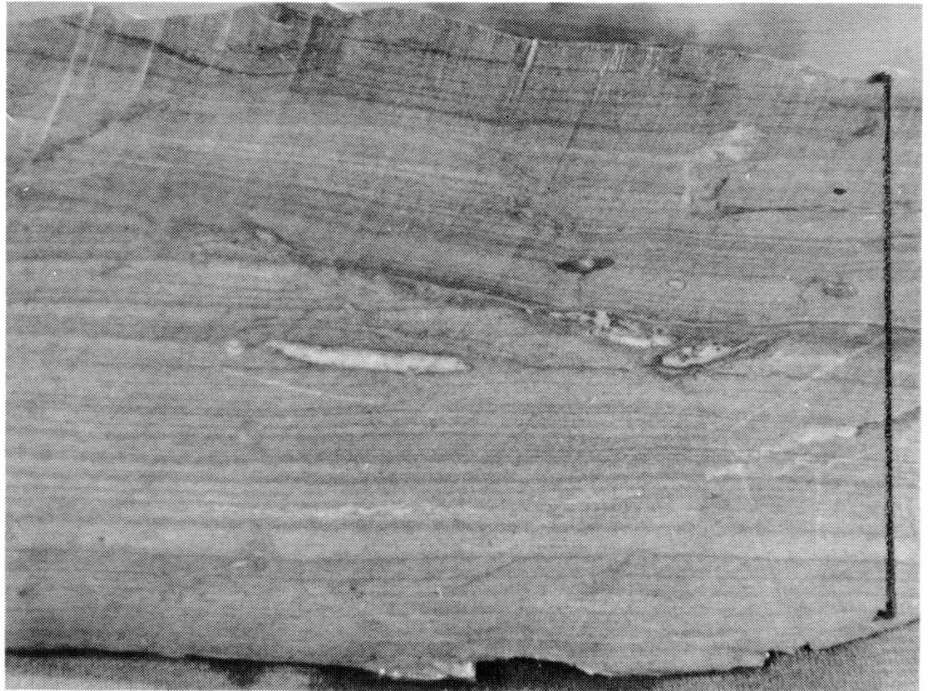

Fig. 8 Two sets of lamination, the lower erosionally truncated by the upper. Light patches are cono cretionary bodies. This type of lamination charo acteristically occurs in siltstone and sandstone immediately above coquinite layers. Bar re= presents $7.7 \mathrm{~cm}$.

Fig. 9 Fossiliferous sandstone with coquina layer at base. Note upward grada. tion in size and generally concaveodown position of shells. Bar re. presents $17.0 \mathrm{~cm}$.

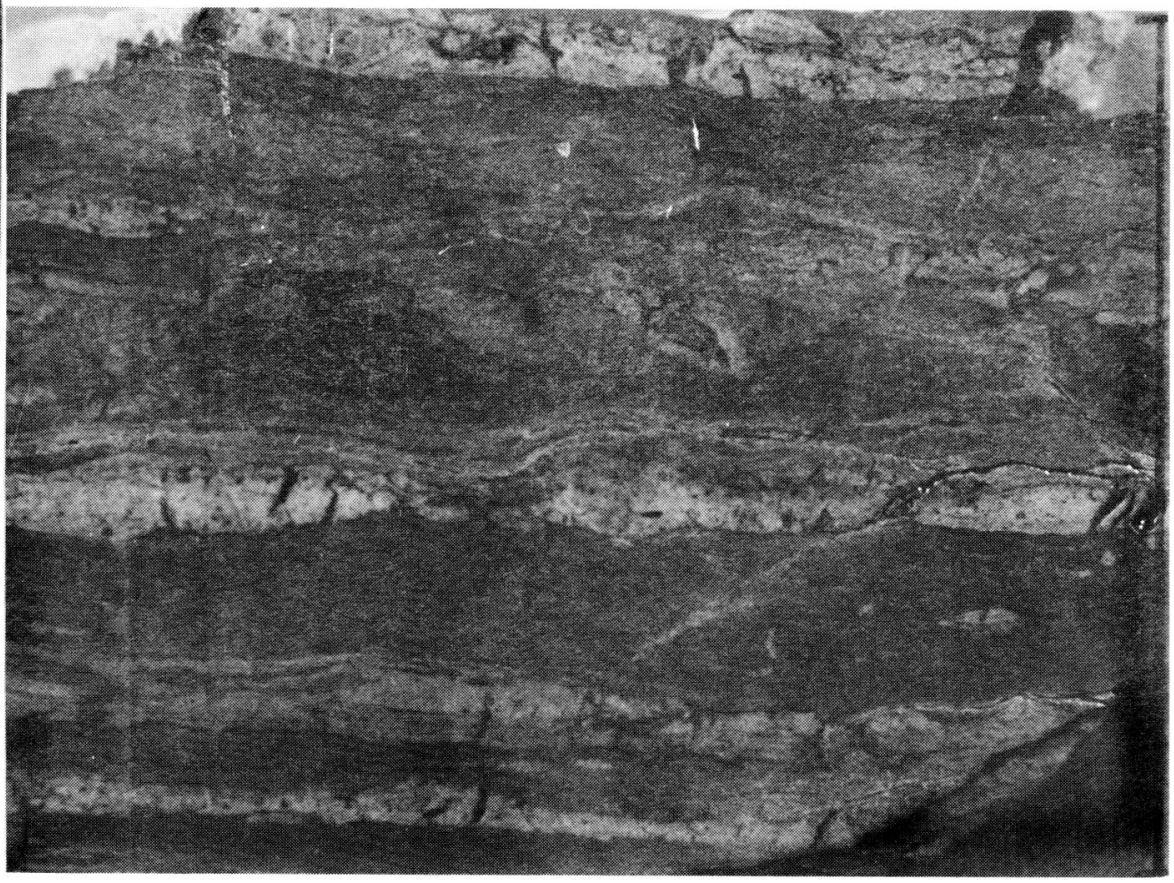




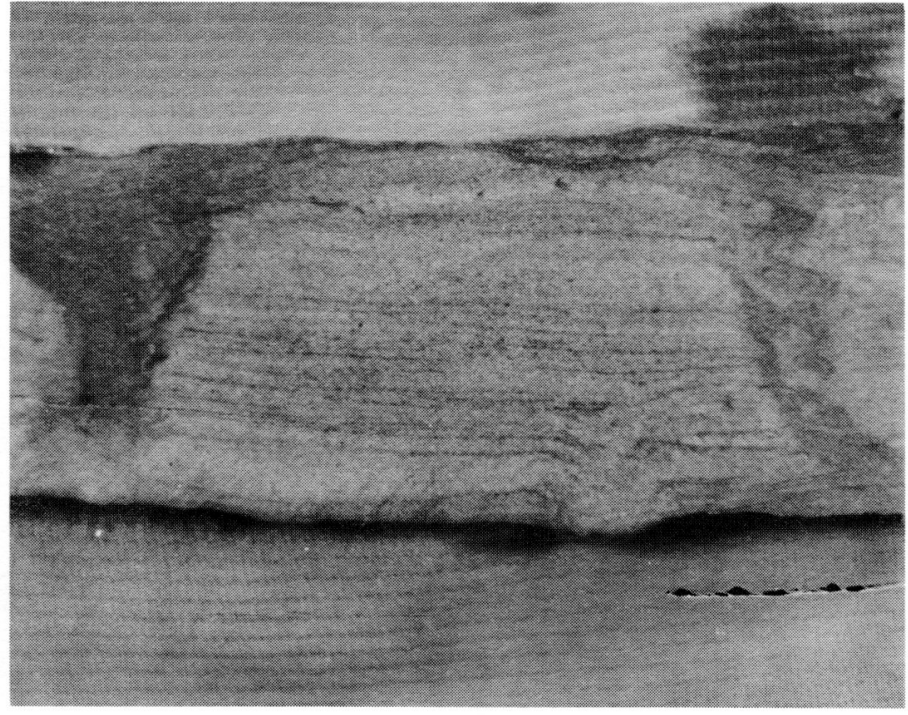

Fig. 11 Sandstone with parallelalamination, grading into weakly developed ripple crosselamination at top. Subovertical burrows cut across and disrupt the laminae. Bar represents $3.0 \mathrm{~cm}$.

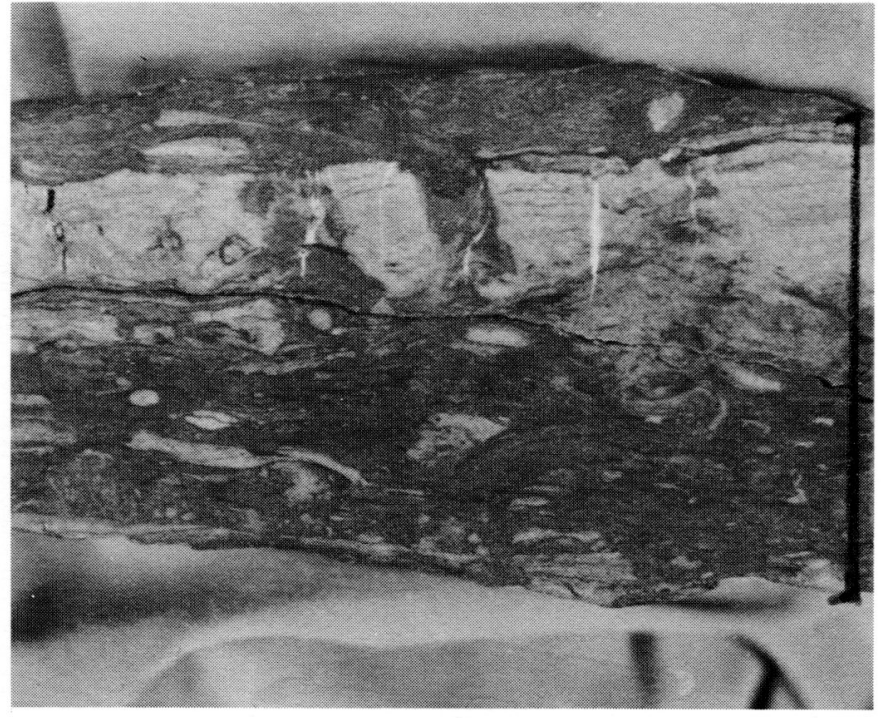

Fig. 12 Highly bioturbated sandstone (1ight coloured) and silty mudstone (dark coloured). Bar represents $5.8 \mathrm{~cm}$.

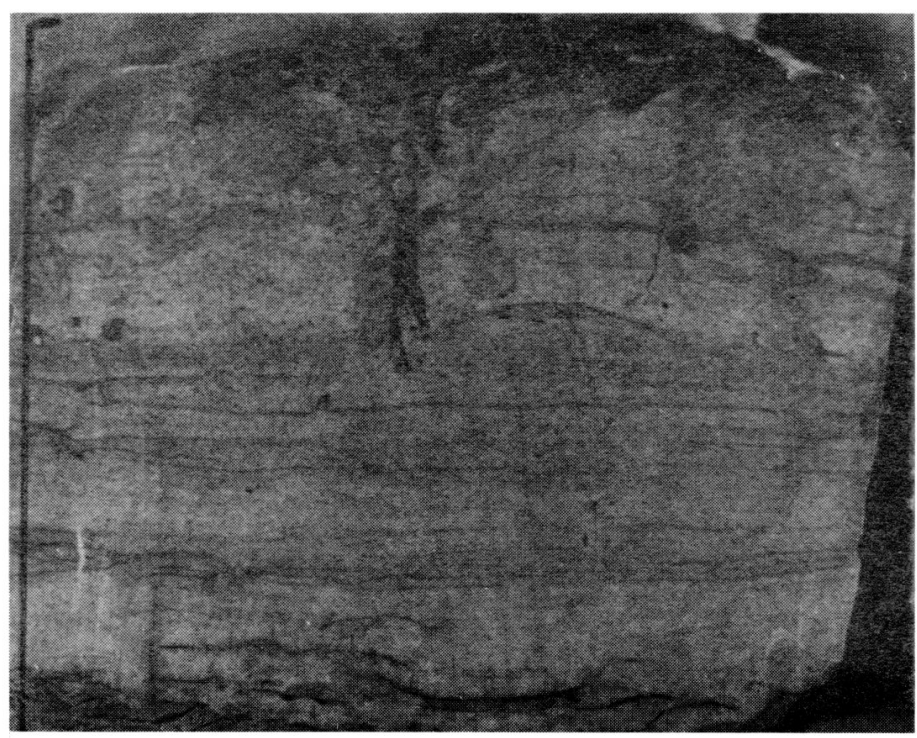

Fig. 13 Sandstone with sub-parallel lamination, progressively more bioturbated towards top. Bar represents $11.0 \mathrm{~cm}$.

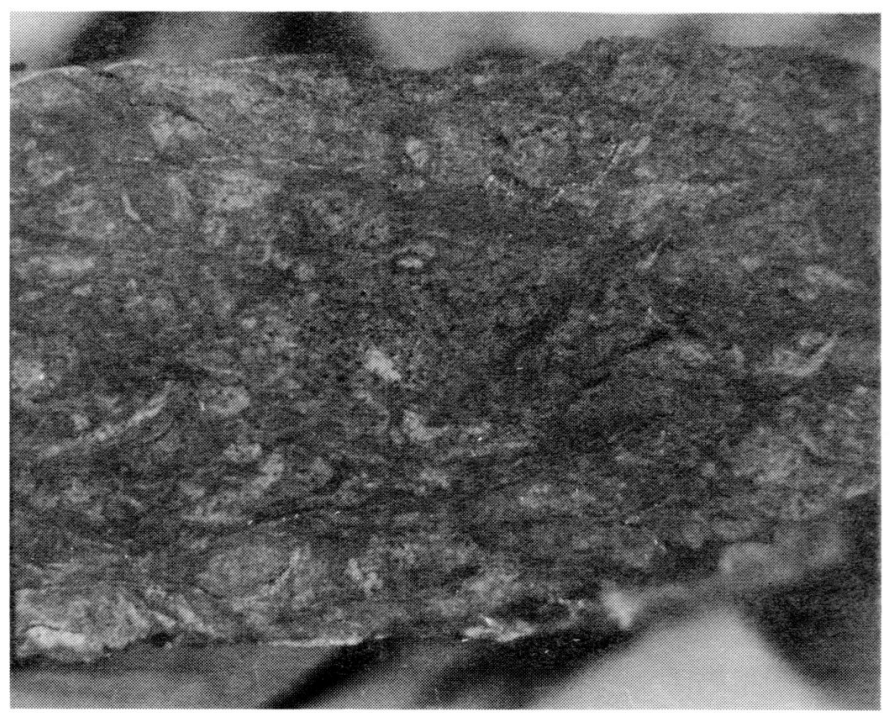

Fig. 14 Highly bioturbated sediment (original stratification completely destroyed). Black particles are granules of phosphate. Bar represents $5.3 \mathrm{~cm}$. 


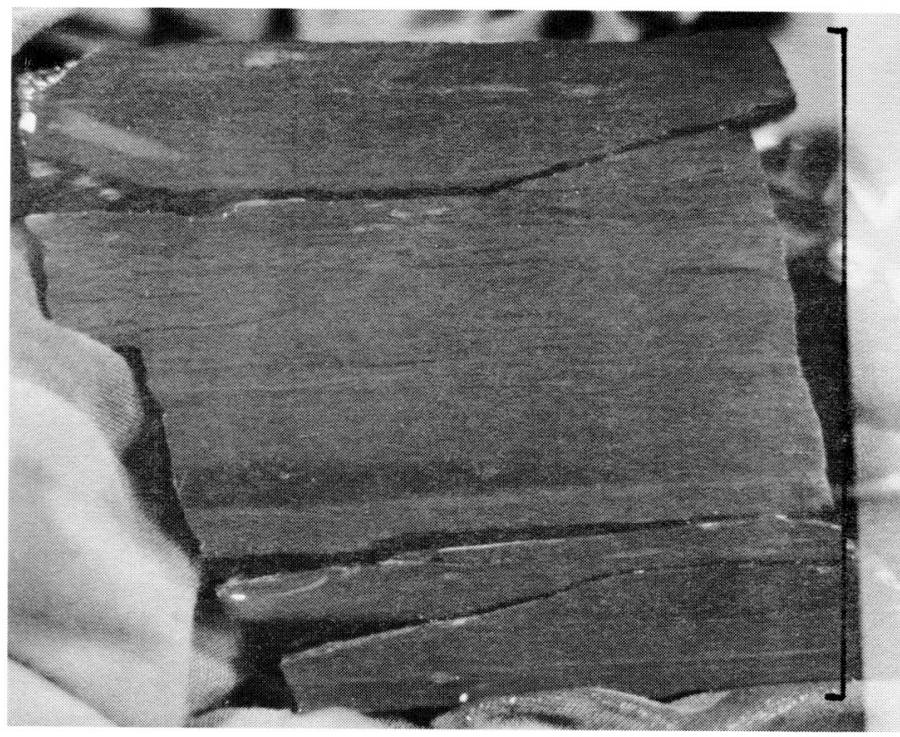

Fig. 15 Silty mudstone with parallelolamination, intero calated with structureless mudstone containing phosphate-rich layers. Irregularly laminated mudo stone with whisps of siltstone near the top. Bar represents $5.2 \mathrm{~cm}$.

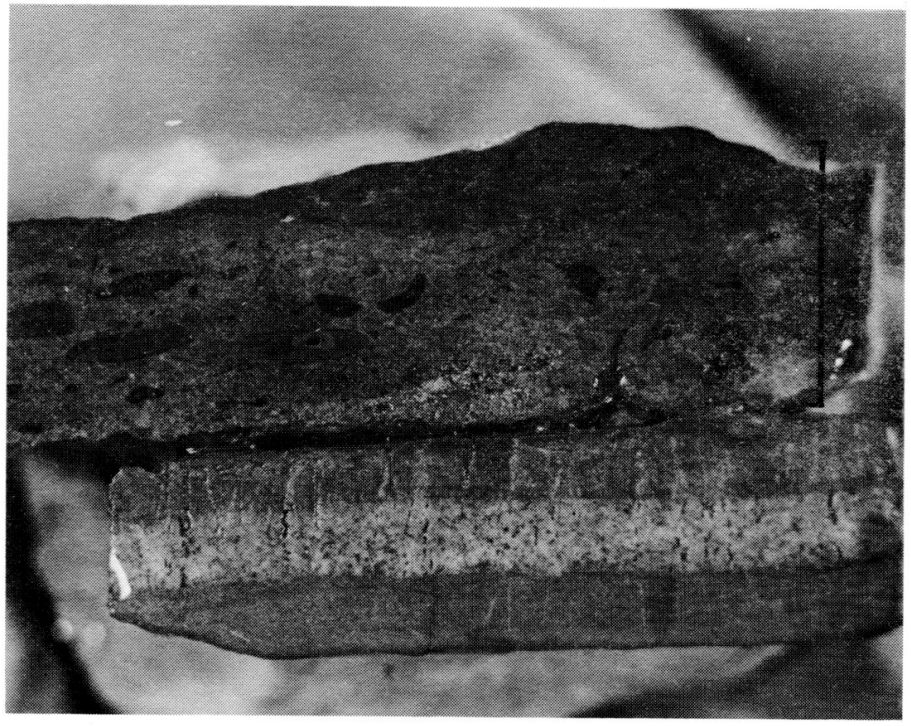

Fig. 17 Intraformational conglomerate with clasts of phosphatic mudstone, above layered sandstone. Bar represents $2.5 \mathrm{~cm}$.

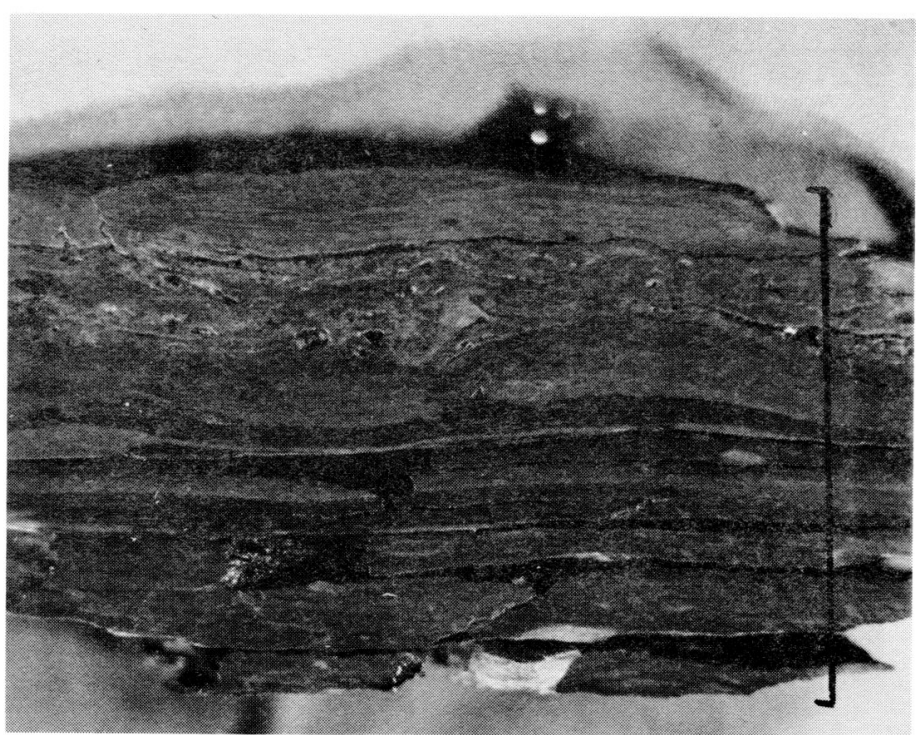

Fig. 16 Clayorich siltstone (whispy and burrowed) passing upward into intercalated muddy siltstone and clay. stone, with fossiliferous sandstone at the top. Bar represents $4.0 \mathrm{~cm}$.

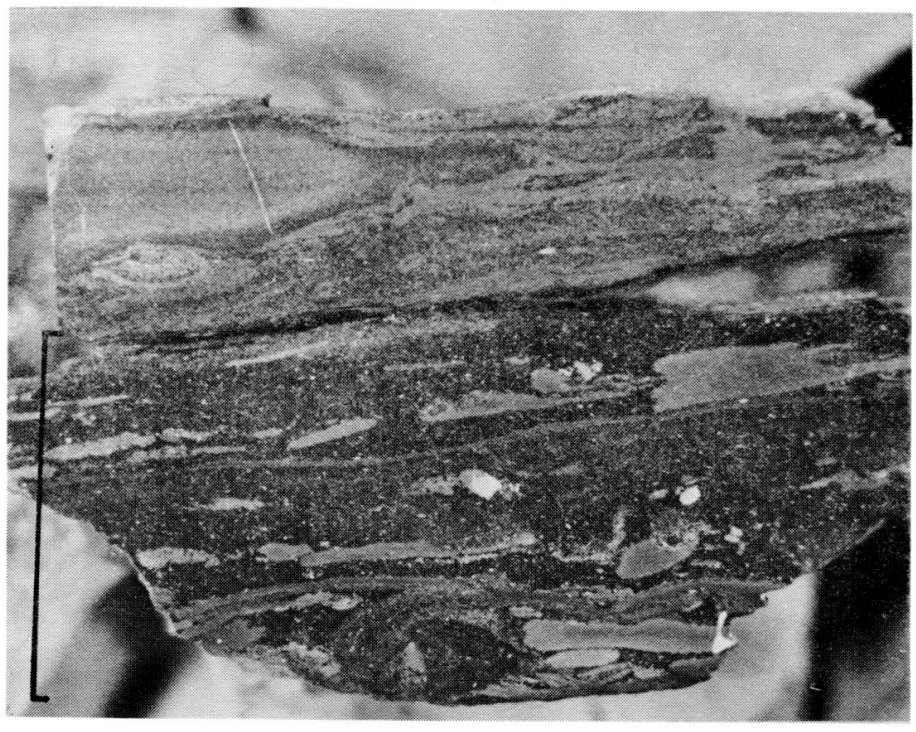

Fig. 18 Oolitic ironerich sandstone containing intraclasts of phosphatic silty mudstone. Bar represents $3.8 \mathrm{~cm}$. 


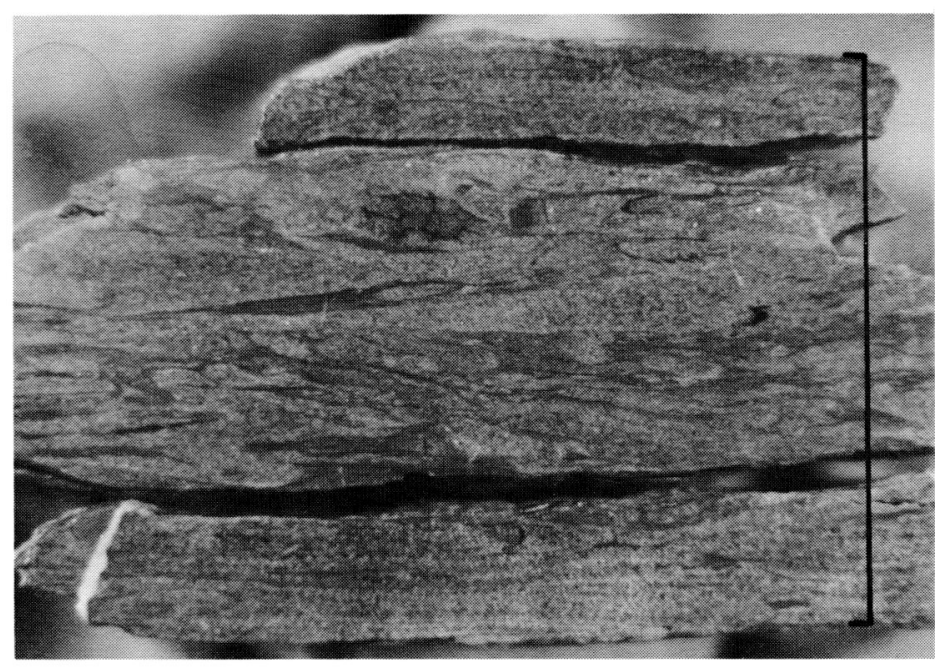

Fig. 19 Sedimentary structures typically found in the arenoceous limestone unit. Note parallel laminao tion, lenticular to flaser bedding, and bioturbotion. Bar represents $5.2 \mathrm{~cm}$.

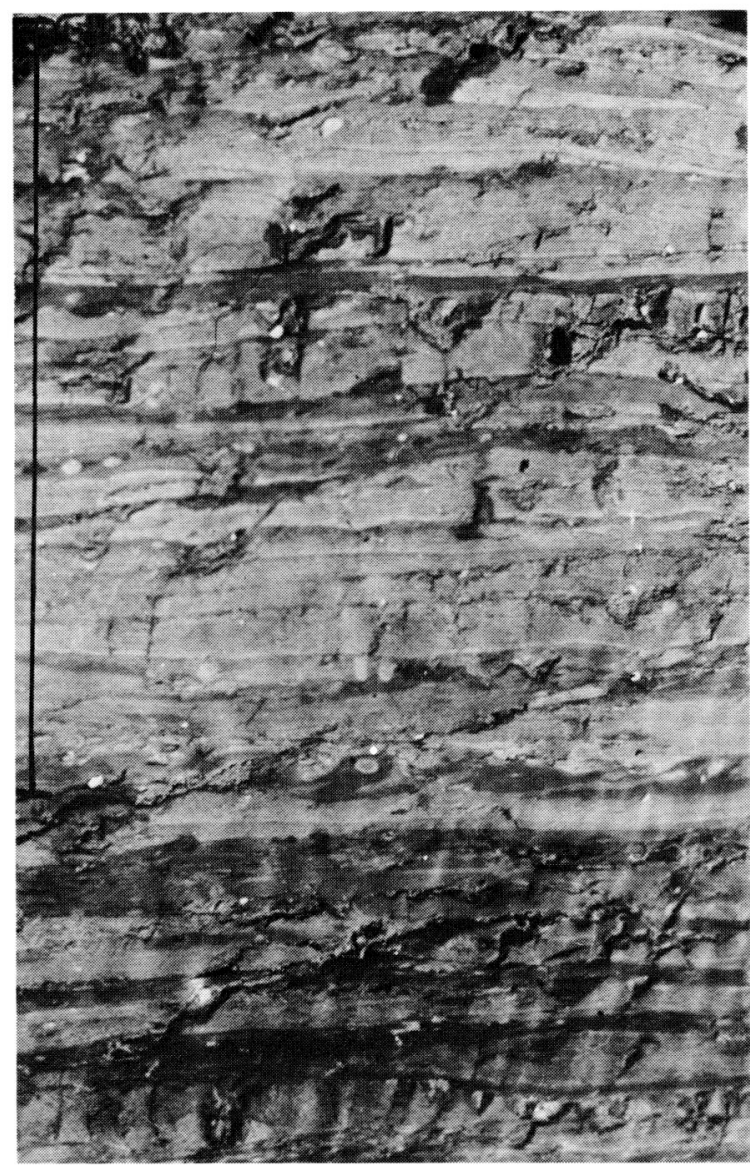

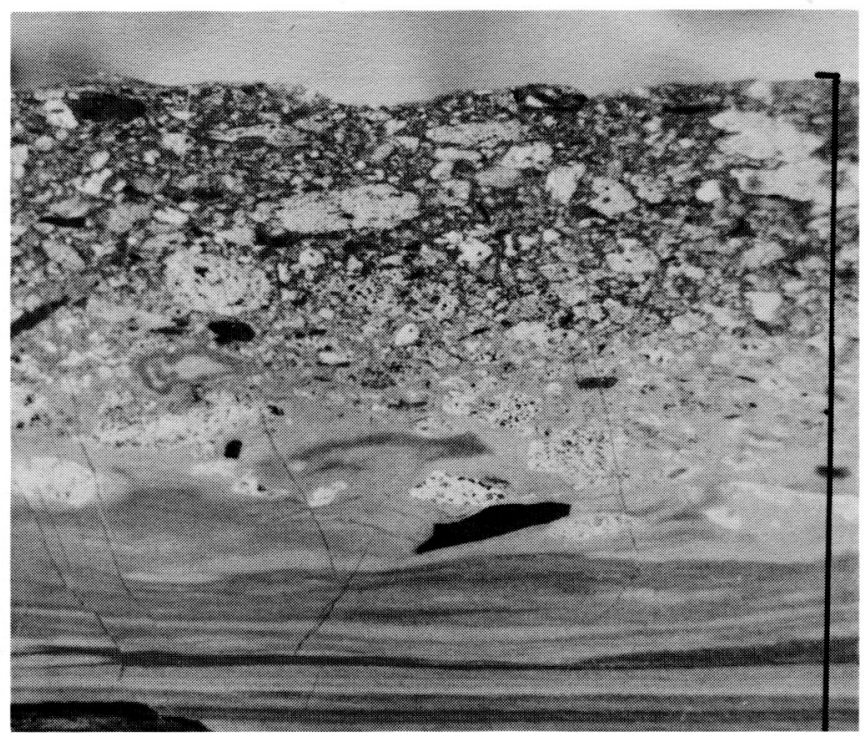

Fig. 20 Volcanic tuff horizon. Lower part contains fine ash, upper part has numerous uncollapsed pumice fragments. Darkocoloured material is phosphatic mud. Bar represents 5.3
Fig. 21 Coarse siltstone and fine-grained sandstone thinly interbedded with cla rich mudstone. Bar represents $15 \mathrm{~cm}$. 

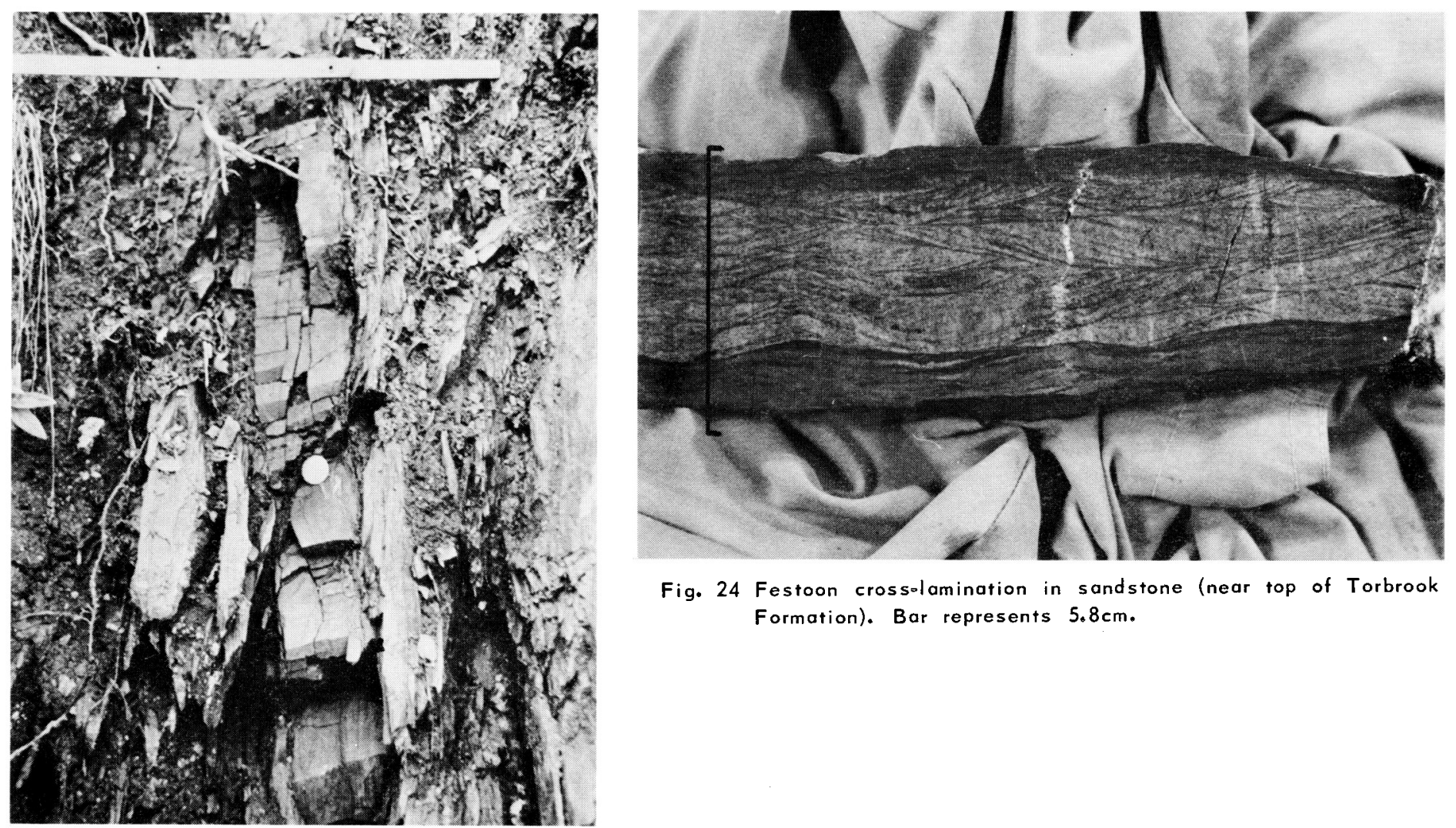

Fig. 24 Festoon crossalamination in sandstone (near top of Torbrook Formation). Bar represents $5.8 \mathrm{~cm}$.

Fig. 22 Sandstone beds (possibly megaripples) in a dominantly mudo stone facies. Coin is Canadian 25-cent piece.

Fig. 23 Interference ripple marks at upper surface of thick sandstone bed. Length of scale is $15 \mathrm{~cm}$.
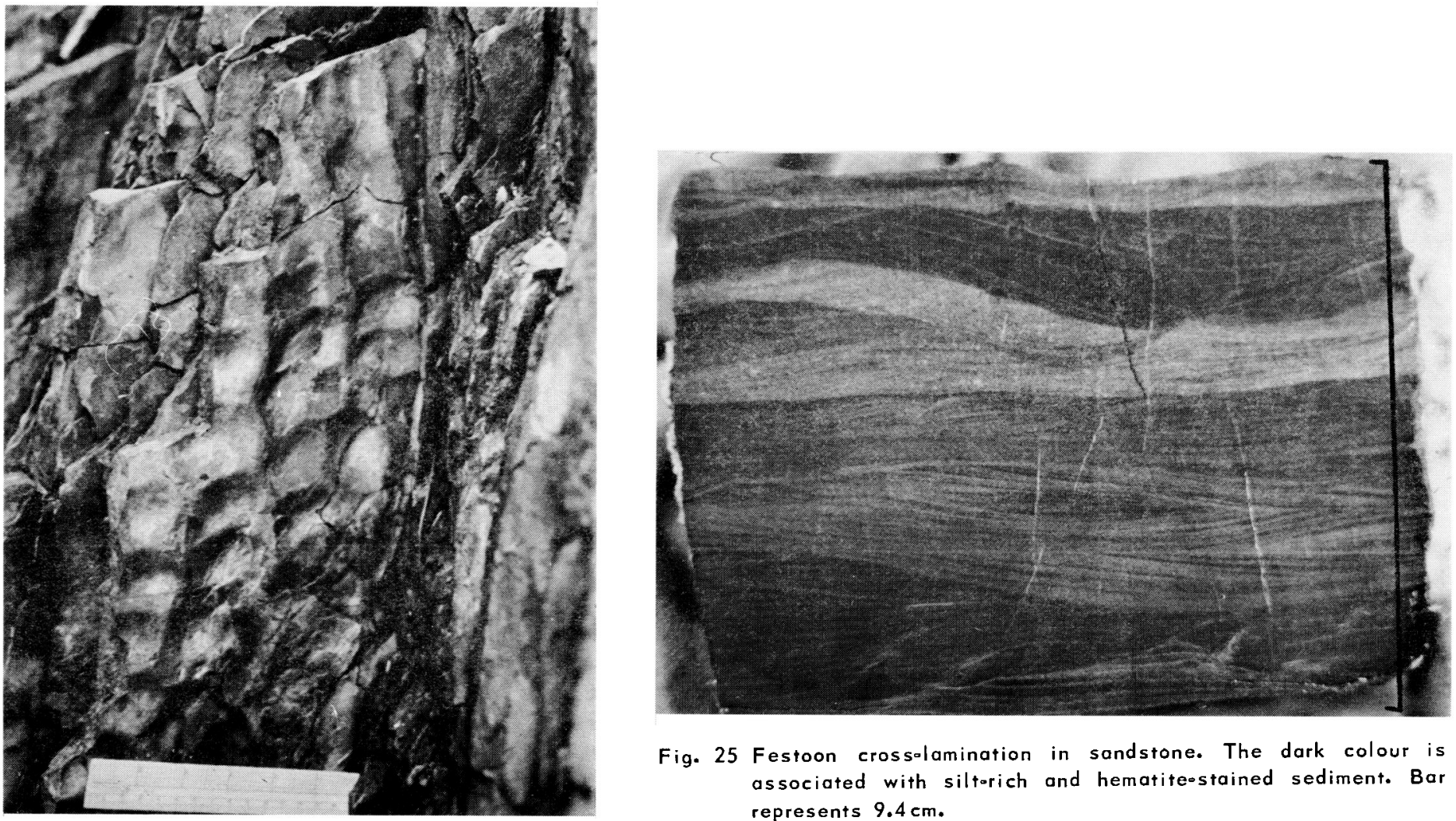

Fig. 25 Festoon crossalamination in sandstone. The dark colour is associated with siltarich and hematiteostained sediment. Bar represents $9.4 \mathrm{~cm}$. 
The itinerary of the Eastern Section SEPM Field Trip includes a visit (Stop 3) to outcrops of the spinney Brook section ( 69 to $175-\mathrm{m}$ interval). The following account focuses attention on the strata of this interval.

The nature of the outcrops is such that the steeply-dipping beds have very limited lateral exposure, but vertical relations and sedimentary structures are generally well displayed. The strata comprise numerous parallel-laminated and low-angle cross-laminated beds of very fine-grained sandstone interbedded with bioturbated mudstone. The mudstone varies in composition from clay-rich to silt-rich (the latter is the more common), and typically is associated with thin sandstone intercalations. Original stratification in the mudstones is rarely preserved due to the effects of intensive bioturbation. However, where it remains the prevailing structures are parallel-lamination and laminae or groups of laminae with a whispy to lenticular aspect. A subtidal as opposed to intertidal environment of deposition is indicated by the absence of emergent features, such as small asymmetrical oscillation ripples superimposed on larger ripples, mudcracks, and in situ plant material.

Non-composite sandstone beds range in thickness from 3 to $40 \mathrm{~cm}$, and composite beds are up to $2 \mathrm{~m}$ in thickness. A number of the beds are lenticular. Compositionally, the sandstone is mainly quartz arenite composed of subrounded to rounded grains. In general, the sandstone beds have flat to gently undulating under-surfaces, but some have uneven under-surfaces due to the presence of distinct scour-depressions. Coquina layers consisting predominatly of unbroken, disarticulated brachiopod shells commonly occur at the base of beds mainly composed of sandstone. Occasionally, small mudstone clasts are interspersed with the shell debris of the coquinas. The sandy material immediately above each coquina layer tends to have either (1) parallel-lamination (Fig. 9), occasionally associated with scoured bases (Fig. 8), or (2) low-amplitude ripple-lamination (Fig. 7). In a number of cases, the parallel-lamination passes upward into ripplelamination (Fig. 10). In general, the sandstones are not graded. However, some beds have a graded aspect resulting from an upward diminution in the size and number of fossil fragments (Fig. $\%$ ). Bioturbation has affected the upper surfaces of many of the beds, particularly those that occur near the top of this interval. The tops of the beds, where not burrowed, commonly are undulatory and, in such cases, the contact with the overlying mudstone tends to be sharp.

This part of the formation contains an abundant fauna, mostly transported and now preserved as coquinites. Platyorthids and spiriferid brachiopods constitute up to $95 \%$ of the fossils in the coquinas at the $134-\mathrm{m}$ and $176 \mathrm{~m}$ horizons. Gastropods are a significant component below the 134-m horizon. A probable in situ fauna Proschizophoria, the bivalve Palaeopecten and fronds of crinoids) occur in transitional layers between mudstone and silty sand- stone beds at the 146-m horizon. Above this horizon, the spiriferid-platyorthid fauna makes up the bulk of the coquinas, vith subsidiary occurrences of small bivalves.

The current directions in this part of the section are quite variable. For example, strata with long, low-amplitude, ripple cross-lamination (mainly in the 108- to 1l1-m interval) appear to be associated with northwesterly and southeasterly current directions, whereas most of the large bottom-scours appear to be associated with currents that moved either from the north or south.

Although most of the sandy beds probably were deposited as a result of storm activity, any of the following types of depositional setting is possible for this part of the section: (1) A simple shoreline and shelf transition (upper offshore region as described for the Sapelo Island area by Howard and Reineck, 1972, and for the oregon shelf by Kulm et al., 1975). (2) The transition zone between shoreface sands and shelf muds of a fairly shallow, marginal sea (including lower shoreface), a modern example of which is the Busum area of the North Sea (Reineck and Singh, 1973). (3) The transitional zone between inner shelf and a complex of tidally influenced marine sand bars such as those that occur at the mouths of estuaries ("sand tongues") of the Nordegrunde, Jorth Sea (Reineck and Singh, 1973). (4) Marine sand bars on broad shelves, disconnected or partially connected with the shoreface (an example is the Holocene of the eastern U.S. seaboard, Swift et al., 1972).

\section{References}

BOUCOT, A.J., 1960, Implications of Rhenish Lower Devonian brachiopods from Nova Scotia; 21st Internat. Geol. Congress, Section 12, p. 129137.

HOWARD, J.D., REINECK, H.E., 1972, Georgia coastal region, Sapelo Islands, U.S.A.: Sedimentology and Biology IV - Physical and biogenic sedimentary structures of the nearshore shelf; Senckenbergiana Marit., v. 4, D. 81-123.

KULM, I.D., ROUSCH, R.C., HARTLETT, J.C. NEUDECK, R.E., CHAMBERS, D.M., and RUNGE, F.J., 1975, Oregon continental shelf sedimentation: interrelationships of facies distribution and sedimentary processes; J. Geology, v. 83, p. 145-175.

REINECK, H.E. and SINGH, I.P., 1973, Depositional sedimentary environments with reference to terrigenous clastics; springer verlag, 439 p.

SWIFT, D.J.P., KOFOED, J.W., SAULSBURG, F.B., SEARS, P., 1972, Holocene evolution of the shelf surface, central and southern Atlantic shelf of North America; in Swift, D.J.P., Duane, D.B., Pikley, 0.II. (Eds.), Shelf sediment Transport: Process and Pattern. Dowden, Iiutchinson and Ross Inc., $656 \mathrm{p}$. 